\title{
Timothy Walker*
}

\section{Medicinal Mercury in Early Modern Portuguese Records: Recipes and Methods from Eighteenth-Century Medical Guidebooks}

DOI 10.1515/asia-2015-1045

\begin{abstract}
This chapter will present and explicate rare information regarding circumstances and techniques for the application of medicinal mercury in the Portuguese medical context during the seventeenth and eighteenth centuries. Through the use of Portuguese medical texts (including translated excerpts), the chapter will provide insight into how early modern Portuguese practitioners processed and employed mercury to treat various ailments. Of interest, too, will be that these remedies were developed at several disparate locations throughout the Portuguese imperial world (China, India, Angola, Brazil, and Portugal), and often drew upon, and blended, indigenous medical substances from the region where each remedy originated. Regarding the use of mercury in South Asian medicine, medical scholars have noted that, from the sixteenth century onwards, much of the intra-Asian (and global) mercury trade was conducted through Portuguese merchants and agents. This work asserts that Portuguese merchants and shippers had unique access both to mercury at the commodity's main sources in Spain and Peru (Almadén and Huancavelica, respectively), but also to established, developed colonial trade routes throughout the eastern hemisphere. Most of the information presented here is excerpted from two little-known eighteenth-century Portuguese primary sources: a Jesuit compilation medical and apothecary guide in manuscript, and a published physician's treatise regarding fevers and other illnesses encountered during a posting of nearly a decade in Angola.
\end{abstract}

Keywords: Mercury, quicksilver, medicine; Portugal; Jesuit; colonial medicine

This article will present and explicate rare information regarding circumstances and techniques for the application of medicinal mercury in the early modern Portuguese medical context in the home country and in various colonial settings

*Corresponding author: Timothy Walker, Department of History, University of Massachusetts, Dartmouth, MA, USA. E-mail: twalker@umassd.edu 
during the seventeenth and eighteenth centuries. Through the use of Portuguese medical texts, including numerous translated excerpts, this work will provide insight into how early modern Portuguese practitioners processed and employed mercury to treat various ailments. Of interest, too, will be that these remedies were often developed at several disparate locations throughout the Portuguese imperial world (for example, in China, India, Angola, Brazil, and continental Portugal), and often drew upon, and blended, indigenous medical substances from the region where each remedy originated. ${ }^{1}$

In considering the surprisingly prevalent use of mercury in early modern South Asian medicine, some medical scholars have noted that, from the sixteenth century onwards, much of the intra-Asian (and global) mercury trade was conducted through Portuguese merchants and agents. ${ }^{2}$ The research conducted for this article agrees with and confirms that view, and further asserts that, due to circumstances rather analogous to the contemporary emerald trade from South America to the Mideast and Asia, ${ }^{3}$ Portuguese merchants and shippers enjoyed close commercial proximity and access to mercury at the commodity's main sources in Spain and Peru (Almadén and Huancavelica, respectively). In addition, Portuguese medical distribution networks relied on well developed, long established Estado da Índia colonial trade routes throughout the eastern hemisphere, as well as familiar commercial pathways in the Atlantic World. So, the movement of medicinal commodities like mercury between colonized areas and the metropôle was not impeded in any unusual way; rather, circulation and employment of mercury as medicine was facilitated throughout the Portuguese imperial system, and its diverse network of ports where Portuguese merchants conducted trade, by pre-existing mercantile conditions. ${ }^{4}$

1 The author wishes to express his gratitude to the URPP Asia and Europe, University of Zürich and the University of Massachusetts Dartmouth; this chapter was made possible through support provided by these institutions. In addition, for research support in Italy, thanks are due to archivist Mauro Brunello of the Archivum Romanum Societatis Iesu (ARSI). For the excerpted passages of José Pinto de Azeredo, Ensaios sobre algumas enfermidades de Angola [“Essays on Some Maladies of Angola”] (Lisbon: Regia Officina Typografica, 1799), I am grateful to Stewart Lloyd-Jones, director of The Contemporary Portuguese History Research Centre, who translated the forthcoming English edition of this work, co-edited by Timothy Walker, Adelino Dias Cardoso, António Braz de Oliveira, and Manuel Silvério Marques (Tagus Press, University of Massachusetts Dartmouth, 2016).

2 Goldwater 1972: 61-65 (I am grateful to Dagmar Wujastyk for alerting me to this reference); and Longworth Dames 2002: I, 46-47, 53-57. See also Brown 1994: 137-149.

3 See Lane 2010.

4 For a description of colonial Portuguese medical trading networks in the Indian and Pacific Oceans, see Walker 2011: 141-170 and Walker 2009: 247-270. 
Most of the information presented here about common Portuguese medicinal applications for mercury during the early modern period will be excerpted from two little-known eighteenth-century Portuguese primary sources: a unique mid-eighteenth-century Jesuit apothecary guide and compilation of medical recipes in manuscript, and a published Portuguese colonial physician's treatise regarding the treatment of fevers and other illnesses encountered during a posting of nearly a decade in Luanda, Angola, at the end of the eighteenth century. The bibliographic references for these sources are as follows:

- Anonymous, Colecção de Varias Receitas e Segredos Particulares das Principais Boticas da Nossa Companhia de Portugal, da India, de Macao e do Brazil (Rome, Italy: Archivum Romanum Societatis Iesu [ARSI]; manuscript, 1766).

- José Pinto de Azeredo, Ensaios sobre algumas enfermidades de Angola (Lisbon: Regia Officina Typografica, 1799).

In terms of methodology and rationale, each of these two examples provides a singular window into the disparate medical cosmologies of contemporary medical practitioners. Beyond illustrating the perspective of the individual authors, though, each document is highly representative of its respective time. Although composed a mere generation apart, the rapidly evolving nature of medical practice in the late eighteenth century is readily apparent in the two texts. The earlier work - a unique distillation of medical practice in multicultural contexts throughout the Portuguese-speaking world - is invaluable for the insight it provides about a range of venerable mercury remedies, long in use across the Portuguese sphere since the seventeenth century and before. Despite the secretive nature of the of Jesuit missionaries who compiled this source, we may be sure that many of these cures circulated widely, and that conventional medical practitioners outside the Jesuits' ranks used them, as well. ${ }^{5}$ The later work, by contrast, is an excellent example that demonstrates Lusophone medical thought in transition, having been newly influenced by closer contacts with northern European medical training during the later Enlightenment Era. As medical practice in the Portuguese world became more cosmopolitan, the therapeutic application of mercury began to adopt methods taught in such

5 The first pharmacopoeia in the Portuguese language, written in 1704 (revised 1711) by Dom Caetano de Santo António, an Augustinian monk from the Monastery of Santa Cruz in Coimbra, contained many similar curative preparations made with mercury; it became the most authoritative Portuguese manual of remedies for physicians, surgeons, and barbers. See Santo António 1711. 
innovative medical faculties as those in Edinburgh and Leiden, where the later text's author had completed his studies. ${ }^{6}$

The principal aim of this article is simply to present new and accurate information about medicinal mercury in historical contexts, as excerpts transcribed and translated from Portuguese primary sources. Thus, this contribution does not aspire to present a larger or innovative theoretical framework, except insofar as this work functions as an integral component to support the comprehensive analytical structure of the present mercury volume. This book, taken as a whole, demonstrates that, across diverse cultures and regions, medicinal uses of mercury were fundamental to many healing traditions. Further, the techniques of mercury application, and the rationale for its use, were similarly disparate and distinct. My chapter serves to elucidate one significant piece of that larger picture.

\section{Some historical context: Portuguese terms for, and sources of, medical mercury}

In the medical parlance of the early modern Portuguese world, a variety of common terms denoted medicinal mercury, or described healing compounds made with mercury, typically as the key active ingredient. Spellings of such terms vary considerably in contemporary manuscript sources; the most common terms and renderings are included below.

One of the more venerable terms for mercury among common folk across the Portuguese-speaking world was azougue (or azogue), which entered Iberian languages through Arabic (a corruption of the word az-zâuq) during the period of North African "Moorish" invasion and occupation (lasting in Portugal from 711 to 1253$).^{7}$ At least until the mid-eighteenth century, Portuguese apothecary compounds containing mercury often referred to the remedy name, and its key ingredient, as azougue. Extant primary sources demonstrate that the word (or variations of it, like azougue vivo) was in common use in continental Portugal and Brazil; the term was likely current in the Asian colonies, as well. ${ }^{8}$

Another common Portuguese term for mercury was cinábrio ("cinnabar" in English), the red ore from which mercury is extracted (known in its powdered

6 Cardoso 2013: 267-276.

7 Disney 2009: I, 51-57, 77-83.

8 Anonymous 1766: ff. 218, 221, 223, 397-398, 456. 
form as "vermilion," a brilliant red pigment used for paint and lacquer). of course, the mines in Almadén, west-central Spain, had been the main source of cinnabar in Iberia since Roman times; indeed, until the modern era, Almadén was the foremost source for mercury in the world. ${ }^{9}$ With cinnabar, or a purer form of mercury extracted from it, one could make calomelanos (called simply "calomel" in English), ${ }^{10}$ a medicinal compound (specifically, mercurous chloride or $\mathrm{Hg} 2 \mathrm{Cl} 2$ ) typically indicated by Portuguese medical guides as a purgative, or mixed into a topical unguent used to treat syphilis or gonorrhea. ${ }^{11}$

Other Portuguese expressions for mercury are more prosaic, and sound similar to their English equivalents. Mercúrio is straightforward, but mercúrio vivo (literally, "live mercury") ${ }^{12}$ evokes the striking signature physical qualities of the metal, which is liquid at temperatures above $-39^{\circ} \mathrm{C}$. Similar names for mercury in Portuguese include prata liquida ("liquid silver"), and argente vivo (literally, "living silver" - but figuratively, of course, the name evokes an idea of metal that flows, similar to the English term "quicksilver"). ${ }^{13}$

Sources of mercury in the Portuguese world depended almost exclusively on commerce with imperial Spain. Continental Portugal produced no appreciable quantities of mercury; nor did the Portuguese colonies. The nearest major sources of mercury were in western Spain, i.e. the extremely prolific mines in Almadén, Castile, and in Spanish-controlled territory in South America, i.e. the Huancavelica mine in Peru. From the mid-fourteenth century onward, the Castilian crown held exclusive control of the Almadén mine; production and export of mercury was thus tightly controlled as a monopoly by royal authority. ${ }^{14}$ Beginning in 1563, mercury production at the Huancavélica mine would amount to approximately one hundred thousand tons over three centuries, but the great majority of its output was directed to sites for processing precious metals at Potosí and other sites in the New World. ${ }^{15}$ Still, some mercury from these sources, allocated for medical uses, undoubtedly found its way to Portuguese physicians and pharmacists operating in the Lusophone metropôle and in the colonies. Even though the Spanish monarchy put in place notably strict regulations and measures to ensure crown profits on mercury, and despite

9 Matilla Tascon 1958: 4-19.

10 Anonymous 1766: ff. 282, 286.

11 Anonymous 1766: ff. 257, 282-83, 285, 291.

12 Anonymous 1766: ff. 485-486.

13 Anonymous 1766: ff. 220-221, 397-398.

14 Goldwater 1972: 62-63.

15 Hernández Sobrino 1999: 2-9; 21-27. 
the fact that most of the output of the Almadén mine was shipped to New Spain by royal order after 1559, a significant quantity was set aside annually for release on the general market in Europe. ${ }^{16}$ Mercury was a controlled strategic substance, after all, regulated because of its value and utility in processing silver and gold in the American colonies.

Trade in mercury from Spain to Portugal may have been facilitated marginally by the union of the Iberian crowns between 1580 and 1640 but, during most of the early modern period, small scale shipments of medicinal mercury, registered with royal customs officials as a legitimate transaction, moved with little impediment between the two kingdoms. ${ }^{17}$ Any illicit cross-border trade in mercury is, due to an understandable lack of documentation, difficult to track and assess, but the existence of some smuggling cannot be ruled out, given the value of the substance and the notorious porousness of the Luso-Spanish border. However, there is no evidence of specific trade regulations that would have necessitated cross-border smuggling. Mercury from Almadén, which lies less than $200 \mathrm{~km}$ from Badajoz near the Portuguese frontier, was transported overland after being packed in leather bags, or in iron flasks, because mercury reacts with and bonds to other metals. ${ }^{18}$ Trains of burros or mules carried this extraordinarily dense, heavy metal from its isolated sources to points of exchange (market towns), or to seaports, where it was transshipped to regions where it was in demand. During the early modern era, the overwhelming majority of refined mercury was utilized for industrial metallurgy, to extract silver from crushed mining ore in the Americas using the amalgamation "patio" method. ${ }^{19}$ Thus, only a relatively small amount of mercury was diverted for medicinal use. In the Portuguese and Spanish context, networks of pharmacies and apothecaries acted as distributors for this specialized medical commodity. ${ }^{20}$

16 Goldwater 1972: 65-66.

17 There seem to have been no explicit restrictions on trade in registered mercury destined outside of Spanish-ruled lands; as long as the mercury sold came from the annual reserve allotted for such trade, this commerce did not interfere with quantities of mercury designated for export to New Spain, and the Spanish crown received the appropriate revenues from its sale. See Stein/Stein 2000: 21-22; Parry 1966: 106-107, 131; and Brown 1994: 137-155. Also see Boyajian 1993: 21-36.

18 Hernández Sobrino 2003: 32-58.

19 Pike $1983: 27-38$.

20 Sousa Dias/Pita 1994: 12-20 and Sousa Dias 1991: II, 609-621. Dias lists the personal medical libraries of five Lisbon boticários (apothecaries), which were included in the inventories of their respective estates, and the inventoried drug stocks of some of the pharmacies they managed. 


\section{Mercury as a medical commodity within the Portuguese sphere}

Now we will consider the practical medical application of mercury in the early modern Portuguese context. How did contemporary medical practitioners approach and view mercury as a medicinal substance? What healing qualities or properties did Portuguese physicians, surgeons and missionaries ascribe to mercury in the seventeenth and eighteenth centuries? Were there significant differences in the ways mercury was used in the metropôle, as compared to the colonies? While there is striking consistency in the medicinal uses of mercury in the Portuguese context when compared to other areas of Europe, the available primary sources that reveal medical uses of mercury seem to indicate that different medical applications for mercury were developed in disparate areas of the Portuguese colonial world, driven in part by varying therapeutic needs, but also by the availability of different indigenous medical substances with which mercury was mixed to achieve well-defined medical ends.

To better understand this diversity of application, we will next consider a range of specific medical recipes containing mercury known to have been in regular use in metropolitan and colonial Portuguese pharmacies, infirmaries and hospitals from the sixteenth to the early nineteenth centuries. Such healing preparations include a mercury-based bolus, and various azougue syrups, each confected for patients on an ad hoc basis to address conditions as varied as constipation, depression, and toothache. ${ }^{21}$ Portuguese physicians and apothecaries indicated the remedy known as "calomel" as a diuretic, a disinfectant, a laxative, and as a topical application to address the symptoms of syphilis and gonorrhea. ${ }^{22}$ Mercury-based ointments and unguents were commonly recommended and sold for body aches, joint pain, and to treat venereal diseases. ${ }^{23}$ Mercury, and preparations containing mercury, were a regular feature on numerous inventory lists of medicines sent to Portuguese colonial medical facilities in the seventeenth, eighteenth, and nineteenth centuries. ${ }^{24}$ However, research for this study has uncovered little evidence of large-scale trade in mercury (for any

21 Anonymous 1766: ff. 282-83, 285.

22 Anonymous 1766: ff. 257, 291.

23 Anonymous 1766: ff. 456, 485.

24 See, for example, HAG MR 46A, ff. 96r-97v (report of medicines and their prices sent from Goa to the Hospital Novo of Moçambique, 1681); HAG 7926, f. 56r/v (report of medicines sent from Hospital Real of Goa to the Fortress of Diu, 1785); and HAG 1346: "Relação dos Medicamentos que fazem precizo para o Hospital Publico Militar dos Ilhas de Soldar e Timor" (Dili, 5 May 1838), f. 183. 
purpose, medicinal or otherwise) through Portuguese colonial trade channels during the period under scrutiny.

\section{Primary sources}

When seeking medicinal techniques involving mercury in the early modern Portuguese world, the first source to consider is the exceptionally rich and revealing apothecary's handbook called Colecção de Varias Receitas e Segredos Particulares das Principais Boticas da Nossa Companhia de Portugal, da India, de Macao e do Brazil. (In English, its title is: “A Collection of Various Recipes and Particular Secrets of the Principal Apothecaries of Our [Jesuit] Company in Portugal, India, Macau and Brazil.”) Written anonymously in 1766 (following the 1759 expulsion of the Society of Jesus from all Portuguese lands ${ }^{25}$ by a member of the Jesuit Brotherhood - a padre who must have been extremely accomplished in the pharmacist's art and methods - the manuscript is held in the Archivum Romanum Societatis Iesu (ARSI, the official archive of the Jesuit Order) in Rome, Italy. This document is a unique, thorough compendium of medicinal recipes taken from Jesuit mission pharmacies established across the Portuguese empire and recorded for posterity in the middle eighteenth century, but containing remedies that had been in use for at least a century, if not longer.

For purposes of this project, the apothecary handbook held in the ARSI is a keystone document: the manuscript contains over three hundred detailed medical recipes (ingredients; proportions; mixing instructions; applications), nearly all employing indigenous healing plants or other substances borrowed from native traditions throughout the Portuguese colonial system (China, India, Africa, Brazil). Mercury is prominent among the medical substances employed throughout the tome's pages. For example, the Jesuit apothecaries in seventeenth-century Brazil confected "Angelic Pills," a "suave” bowel purgative containing mercury, locally-sourced jalapa and fennel oil. ${ }^{26}$ Thus, this pharmacy guide represents - and demonstrates in a single work - the extent of globalization, cultural borrowing, and methodological hybridization achieved in Portuguese imperial medical practices. ${ }^{27}$

In assessing the means by which this global transfer of medical information occurred (effected through Portuguese colonial agents: maritime commanders,

25 Alden 1996: 651-660.

26 Leite 1953: 289. The recipe for this medicine is found in Anonymous 1766: f. 275.

27 Anonymous 1766: ff. 1-280; Walker 2009: 255-256, 260-262. 
colonial administrative officials, religious missionaries and state-licensed medical practitioners), my attention fell primarily on Roman Catholic missionary institutions, the Jesuits foremost among them. Catholic missionary brotherhoods, including the Franciscans, Dominicans and others, were of course exceptionally active across the Portuguese empire, attempting to achieve broad religious conversions among colonized populations. In their annual reports from the mission fields, Jesuit padres openly acknowledged the strategic utility of gathering information about indigenous remedies and demonstrating a prowess with healing arts for furthering their evangelizing activities. ${ }^{28}$ In time, Jesuit missionaries would develop the primary European body of expertise about indigenous medicine in the Portuguese colonies. Missionary orders, recognizing also the potential for profit from commercializing native drugs, quickly became the principal commercial disseminators of these healing commodities and the specialized knowledge of how to prepare and use them throughout the Portuguese maritime world. ${ }^{29}$

The Jesuits in particular systematically gathered and disseminated empirical and practical ethno-botanical information, beginning almost from the moment of their arrival in colonized regions in the sixteenth century. Their numerous extant field manuals detail indigenous healing plants and remedies with striking precision and a marked respect for local knowledge. ${ }^{30}$ As near monopolists in the global trade of indigenous medicinal substances within the Portuguese mercantile system during the sixteenth, seventeenth and eighteenth centuries, missionary orders relied on this revenue to support their evangelical operations throughout the Portuguese overseas territories. ${ }^{31}$ Most permanent Jesuit colonial missions around the world operated medical facilities - typically an infirmary and a pharmacy - from which they dispensed medical compositions for a profit. In fact, a Jesuit missionary's standard education prior to departure prepared him for two specialized types of healing work, either as a nurse (who might also perform minor surgeries), or a pharmacist. ${ }^{32}$ In 1576, Pope Gregory XIII issued a dispensation allowing appropriately trained Jesuits to perform duties as

28 For example, see the Shembaganur Province Archives, Sacred Heart College, Kodaikanal, Tamil Nadu, India; Annual Jesuit Missionary Letters of the Malabar Province; Shelf 211, Book 34 (1606-1643), 30-44, 47-50, 52-53, 78; Book 102 (1655-1666), 87-91, 221-227.

29 Walker 2009: 264-270.

30 See, for example, BNF, Manuscripts, Fonds Portugais No. 59, Breve compendio de varias receitas de medicina (1598), ff. 2-79v; and BNRJ, Manuscripts Division; Nr. I-15, 02, 026, Curiosidad; un libro de Medicina escrito por los Jesuitas en las Misiones del Paraguay en el año 1580, ff. 1-280.

31 Walker 2013: 414-420.

32 Leite 1953: 83-89. 
physicians in areas that otherwise lacked access to (implicitly European) medical care. ${ }^{33}$ To be sure, Jesuit mission apothecary shops, stocking remedies from around the world, were a common feature throughout European settlements in the Portuguese empire. Most colonial communities of any regional importance had been pioneered by and settled around a Jesuit mission; the resident padres were often the sole resource for learned medical consultations in any given region. ${ }^{34}$ Hence, the introduction and popularity of mercury-based remedies in many colonized areas can be attributed to their practices.

\section{Mercury-based medicines in the Colecção de Varias Receitas e Segredos Particulares das Principais Boticas da Nossa Companhia}

The following is a selection of a dozen representative Jesuit medical recipes drawn from the pages of Colecção de Varias Receitas e Segredos Particulares das Principais Boticas da Nossa Companhia... All twelve contain mercury as a fundamental active ingredient.

\subsection{Mercúrio sublimado doce ("Sweet sublimated mercury")}

Sweet sublimated mercury is one of the first mercury-containing remedies included in the guide; it seems to have been formulated originally in pharmacies in continental Portugal and then circulated to other imperial locations. The active ingredient for this powdered healing preparation was azougue vivo, or quicksilver. Preparing the mixture involved prolonged heating (eight to ten hours) using, according to the instructions, special apothecary glass jars to achieve the correct sublimation process. ${ }^{35}$ The "virtues" of the finished substance (its applications and expected efficacy) are described as follows: "Serves to remove all [bowell] obstructions; to purify the blood; to kill [intestinal] worms

33 O’Neill/Dominguez 2001: III, 2601-2602.

34 Santos Filho 1947: I, 112, II, 26-30.

35 Historically, sublimation is a rudimentary chemical process used by alchemists during the medieval and early modern period, in which a substance is heated to a vapor, which then immediately collects as sediment on the upper portion and neck of the heating medium (typically a special glass flask called a retort or alembic). See Leicester 1956: 70-95. 
(called lombrigas in Portuguese); to cure 'buboes;' to purge the [colon] chamber of bloody [and/or] putrid humors; in particular if it is mixed with a hydrogogue medicine [cathartic that promotes watery evacuation of the bowels]." The instructions hint at a budding understanding that this medicine might ultimately be harmful, noting that if the compound "is administered for a prolonged time it promotes [excessive] salivation.”36

\subsection{Mercúrio doce lavado ("Sweet washed mercury")}

The recipe for this remedy was first created in the apothecary shops of the Jesuit College in Salvador da Bahia (founded 1549), the principal Jesuit mission center in Brazil. ${ }^{37}$ Ingredients included powdered sublimation of azougue vivo (quicksilver/mercury), agua régia or agua forte (a strong distilled alcoholic beverage, like brandy or Italian grappa), and salt water. All components were to be stirred together in a wide-mouthed glass flask and left in direct sunlight for an hour until the mixture started to bubble. This remedy was to be taken internally by mouth to provoke a "flux" - that is, a gastro-intestinal evacuation. In terms of its recommended use and efficacy, the handbook states that this remedy could also be applied externally with "very good success, mixed as a pomade for scabies, ringworm, eczema, herpes, and other skin corruptions." 38 For application on the skin, readers were advised to blend a quantity of one-eighth of an ounce of the sublimated mercury powder in each ounce of common pomade or unguent (a base typically composed of animal fats blended with white wax). ${ }^{39}$

\subsection{Mercúrio Alkalissatus}

The genesis and meaning of this remedy's name are obscure; it could be a nonsense moniker chosen simply to invoke images of exotic lands - and consequent perceived medicinal efficacy derived by association with them. Lending credence to this idea is that the compound's recipe appears to have originated at a Jesuit apothecary in continental Portugal, possibly one associated with the Monastery of São Vicente or the Church of São Roque in

36 Anonymous 1766: ff. 218-220.

37 Leite 1953: 32-41.

38 Anonymous 1766: ff. 220-221.

39 Anonymous 1766: ff. 456, 485. 
Lisbon. ${ }^{40}$ Ingredients for this medicine, meant to be a general restorative, were very simple: plain mercury, ground together with olhos de caranguejo (crabs' eyes from Brazil that gave the compound a bright red color $)^{41}$ or, failing that, a fine, especially prepared red coral. The instructions advise the reader to carefully blend all ingredients together on an apothecary grinding stone (a common piece of equipment much like a metate) until the mercury could not be seen. If the medicine was not to be administered right away, the practitioner was warned to store the mixture "in a well-sealed glass [bottle or jar] until ready to use." 42 This remedy's virtues were not named specifically: the medicine was said to be a "grand alterative" to other similar preparations useful for gradually restoring healthy bodily functions (apparently by promoting a thorough evacuation of the bowels, thereby balancing the body's humors, in accordance with the tenets of contemporary humoral medical concepts). Recommended dosage began at ten grains of the mixture, but could be increased if symptoms persisted.

\subsection{Panacea Mercúrial (“Mercury panacea”)}

Another mercury-based, general-purpose remedy - indeed, a medicine termed a "panacea" - originated in the pharmacy of the venerable Jesuit College of Bahia, Brazil. This simple but time-consuming recipe calls for mixing wine spirits (strong brandy) with calomel that had been repeatedly sublimated a total of twelve times. According to the handbook, to be successful, this process involved heating the remedy slowly over a fire for fifteen days; the medicine had to be mixed daily, and thoroghly cooled and dried between each heating. Medical applications varied: "Taken internally, this panacea serves for all types of gallico [that is, French, or venereal disease], [intestinal] obstructions, scorbutic ills [scurvy], intestinal worms and, [applied] externally, for scrofula, and herpes, and any excoriation of the skin ..."43 By mixing this medicine with other substances - for example, with "flower of sulfur" and common oil - one could make a liniment with which to anoint the wrists, armpits and legs; this was intended for treating eczema. The apothecary instructions called for applying the liniment at night over three consecutive days.

40 Dias/Pita 1994: 12-20.

41 Walker 2013: 415.

42 Anonymous 1766: f. 223.

43 Anonymous 1766: ff. 256-257. 


\subsection{Pillulas de Familia ("Family pills")}

The pharmacy of the Jesuit College of São Antão in Lisbon, noted for innovative scientific experimentation in the seventeenth century, ${ }^{44}$ provided the recipe for a multi-purpose medicine called "Family Pills." Apparently these were an early prepared household cure-all available to Lisbon's middling and upper classes who could pay the not inconsiderable price - they were the forerunner to later patent medicines aimed at a similar market. This medicine's exceptionally diverse range of ingredients included an extract of Socotra aloe, jalapa resin from Brazil, extract of colocynth (a bitter apple), scammony (a weed native to the eastern Mediterranean, used as a purgative), "Benedictine extract" (possibly a medicinal herbal liqueur, the medieval recipe attributed to French Benedictine monks), gutta gamba (a gum resin), vitriolic tartar (potassium sulphate), extract of saffron, castor oil, Indian cloves, "flower of nutmeg" (mace), a syrup prepared with "Saint Gregory's cucumbers," and a so-called "Turkish” mercury preparation called calomelanos Turquescos. ${ }^{45}$

The handbook indicated that the components of this remedy must be slowly cooked over a mild fire and mixed; then "formed into pills of a common size" in a dose "between two and three grains per pill." 46 The remedy was to be administered "at the same time each day, either at night when laying down to sleep, or in the morning with an empty stomach before breakfast, or at any hour of the day or night, three hours before or after eating." Describing this remedy's "virtues", the Jesuit author wrote that, taken as drops, Family Pills serve "for all types of scurvy, for gallica [that is, Gallic, or venereal disease], hydropsy, and for any type of [intestinal] obstructions."47

\subsection{Pillulas para desecar Gonarreas ("Pills to desiccate gonorrhea")}

Medicines concocted specifically to address venereal maladies were neither rare nor obscure in the Jesuit pharmacopeia. On the contrary, no attempt was made to veil or refer euphemistically to such illnesses, because addressing sexually transmitted diseases was, not surprisingly, a common facet of the work Jesuit pharmacists throughout the Portuguese maritime colonial world were called

44 Leitão 2007: 2-11.

45 Anonymous 1766: f. 282.

46 Anonymous 1766: f. 283. See also Maia 2012: 224-225.

47 Anonymous 1766: f. 283. 
upon to undertake. Moreover, such remedies generated steady, reliable profit. The secret remedy handbook's author attributes this recipe, apparently composed in Lisbon or possibly Brazil, to one Frere Manuel de Carvalho, who is described as a "junior apothecary" in the Jesuit brotherhood. ${ }^{48}$

Brother Carvalho's ingredients consisted of powdered pine resin, the mercury-based compound calomelanos; the powdered gum of pau santo (literally "holy wood," a valued medicinal herb sourced from the interior of Brazil ${ }^{49}$ ), a pungent black Peruvian balsam, and a syrup made with althea (also known as the marshmallow plant). However, another recipe for a remedy of the same purpose, provided alongside the young Carvalho's mixture, contained mercúrio doce ("sweet mercury"), camphor, "Saturn" salt, turpentine "cooked to the point of burning," and althea syrup. These ingredients were to be milled together on a grinding stone and formed into pills or a bolus "of ordinary size" - interestingly, the mixture was not meant to be applied topically. The medicine was for ingestion, taken for fifteen consecutive days "in the morning before breakfast, with eggs and rosewater," after which time the outward effects of the patient's gonorrhea affliction were expected to be dried and cured. ${ }^{50}$

\subsection{Pillulas Mercúrias (“Mercurial pills”)}

A very simple medical recipe, the Jesuit apothecary handbook nevertheless asserts that these mercurial pills "are given with happy success to purge venereal infirmities, for obstructions, for melancholy, and in all other infirmities that stem from unbalanced humors."51 Moreover, the author felt compelled to warn that such pills "are potent."

Three ingredients made up this remedy: mercúrio doce, powdered potato resin, and common drinking water. The components were to be blended, ground into a paste or dough in a mortar and pestle, formed into "ordinary-sized" pills and then left to dry. Taken orally, the curative effects were expected to be almost immediately apparent. A similar mercury-based pill or bolus recipe found on the same page, "Pillulas Contra Obstrucções Gallicas e Males de Cabeça," promised to address "headaches and venereal obstructions." 52

48 Anonymous 1766: 285.

49 Albernaz et al. 2010: 116-119.

50 Anonymous 1766: f. 286.

51 Anonymous 1766: f. 291.

52 Anonymous 1766: f. 291. 


\subsection{Pós contra Lombrigas ("Powders against intestinal worms")}

According to notations in the handbook, this recipe originated at the apothecary of the Jesuit College of Saint Paul in Macau, the Portuguese enclave in southern China. Since the late sixteenth century, this ecclesiastical pharmacy had been supplying medicines - often compositions combining Asian and European ingredients - to mariners from all Western trading nations who arrived to trade for goods from Canton. ${ }^{53}$ The mercury-based medicinal powder here described was given as a specific to kill intestinal worms, "and to expel them from the system in due course." 54 This is one of two Jesuit remedies for intestinal worms included in the apothecary guide that contained mercury.

Ingredients for this remedy included several obscure components: powdered "seeds of Alexandria" and "fired diaforetic mercury" (mercúrio diaforetico em fogo), powdered coralline (a coral-like algae), powdered aloe resin, and powdered jalapa imported from Brazil. The author noted that the medicine required several days to appropriately compose and dry the ingredients. When blended together in the recommended quantities, the recipe was supposed to make six doses, to be ingested twice per day over a period of three days - taken once in the morning before breakfast, and once in the middle of the afternoon. The author recommended that the medicine be swallowed with "something sweet, followed by three or four ounces of water." 55

\subsection{Tizana laxativa Mompliacensis ("Mompliacensis laxative infusion")}

According to the handbook, the recipe for this laxative tea was formulated at the Jesuit mission apothecary in Recífe, Brazil, though it is thought to have been based on an earlier French recipe brought from the medical faculty at Montpelier. ${ }^{56}$ Ingredients for this extraordinary infusion included locallysourced salsaparilha, pau santo, contrayerva (an aromatic root and mild stimulant), sassafras, and white sugar. Additional ingredients from further afield included "raw" antimony (the metallic sulfide mineral stibnite, similar in appearance to lead), powdered pumice stone, azougue vivo (mercury), juniper

53 Amaro 1992: 7-11.

54 Anonymous 1766: f. 320.

55 Anonymous 1766: ff. 319-320.

56 Leite 2013: 68-78. 
root, oats, and cracked barley. All the ingredients were boiled together into a mash in a double boiler, after which the liquid was drained off and served as tea. ${ }^{57}$

"Virtues" (the indications and applications) for this tonic tea were given as follows: "This remedy serves for any Gallic infection [venereal disease]; apply it by taking in the morning and afternoon until [the entire infusion] is finished." 58 In an unusual detail, the apothecary handbook also noted the cost of creating this recipe. Using contemporary Portuguese currency, the remedy's price was 1280 reis per infusion, which made it quite an expensive medicine to prepare. To give a rough idea of the value of this sum, Portuguese Inquisition agents, called familiares, received 500 reis per day at the beginning of the eighteenth century when performing duties for the Holy Office; this amount was about twice the daily pay of a journeyman laborer in contemporary Portugal. ${ }^{59}$ In other words, one dose of Tizana Laxativa Mompliacensis cost more than five days' wages for the average worker.

\subsection{Unguento de azougue (Mercurial unguent)}

This popular mercury-based unguent, or salve, is another recipe attributed to the prolific apothecary staff of the Jesuit College in Salvador da Bahia, Brazil. To make this balm, the Jesuits mixed a base of white wax with fine turpentine, and combined it with an unguent made from the native Brazilian plant bicuíba (part of the nutmeg family). To this they added "Balsam of Brazil" (a separate medication made with indigenous medicinal plants), pure azougue vivo (mercury), and lard taken specifically from a male pig. ${ }^{60}$

Apparently this medicine could function as a strong purgative when taken internally, since among its "virtues" is given the following: "Serves to excite the flux from the mouth with great brevity..."61 However, the salve could also serve as a topical ointment "for any type of 'Gallico' [sexually-transmitted disease], old-style buboes, scabies, and skin eruptions...;" as indicated in the handbook, one could apply it to "all of the articulations [joints], spreading it [broadly] over some space, periodically, whenever necessary."62

57 Anonymous 1766: ff. 397-398.

58 Anonymous 1766: f. 398.

59 Regimento dos Familiares do Santo Ofício 1694, ff. 173-174.

60 Anonymous 1766: f. 456.

61 Anonymous 1766: f. 456.

62 Anonymous 1766: f. 456. 


\subsection{Unguento para Sarna (“Unguent for scabies or mange”)}

The author of the Jesuit apothecary handbook advised that this mercury-based unguent could be used for any skin ailments, like scabies or mange (the general Portuguese term for which is sarna), "even if [the symptoms are caused by] Gallica [venereal disease]." ${ }^{63}$ Besides using both mercúrio vivo and "corrosive sublimated mercury" in combination, the ingredients for this balm included "washed" white lead, turpentine, olive oil, wax, and common "pork butter" (lard). Directions for the composition instruct the pharmacist to

Heat and mix the fatty ingredients together in a glazed ceramic bowl; let cool, and then mix in the mercury. Let cool and store in a glass vase or jar. ${ }^{64}$

Applications and uses for this medication were given as follows: "Virtues: serves for any kind of scabies or mange; spread it for three days, in the morning and at night, on the hands, wrists, in the armpits and on the curves of the legs" (that is, behind the knees). ${ }^{65}$

\subsection{Unguento contra Piolhos ("Unguent against lice”)}

This simple balm, employed to rid the body of lice, consisted of just two ingredients: a rose-based and scented unguent ("unguento rosado"), and mercúrio vivo. These were to be mixed "in a stone mortar until the mercury no longer appears in the unguent ..."66 To preserve the mixture and avoid contact with metals with which mercury would react, the composition was to be stored only in a glass or glazed ceramic jar.

Regarding the balm's "virtues," the handbook states that this unguento contra piolhos "serves to kill lice; apply by greasing a cord [with the unguent] very well, tying the cord around the waist, if the lice are walking on the body, and if they are on the head, around it." 67 The handbook describes this preparation as being "great" [óptimo] for this intended purpose.

63 Anonymous 1766: f. 485.

64 Anonymous 1766: f. 485.

65 Anonymous 1766: f. 485.

66 Anonymous 1766: f. 486.

67 Anonymous 1766: f. 486. 


\section{Mercury-based medicines in José Pinto de Azeredo's Ensaios sobre algumas enfermidades de Angola (1799)}

Authorship of our next primary source text for medicinal mercury is undisputed: He was a prominent and peripatetic Brazilian-born physician named José Pinto de Azeredo (1764-1810). His unique treatise, based on eight years of clinical practice in Angola, provides modern researchers with a valuable window into the methods and rationale for the medical application of mercury in Portuguese colonial Africa at the end of the eighteenth century.

Azeredo's scholarly tendencies were driven in part by his exposure to robust scientific inquiry during his years as an impressionable medical student in Edinburgh (1786-1788) and Leiden (1788-1789), but he also found great freedom to innovate as a young independent physician in Angola, where he served as the chief medical authority in the colony from 1790 to $1797 .{ }^{68}$ Azeredo's medical training followed a well-worn path; he and his brother were among a significant group of Portuguese subjects to travel to northern Europe for medical studies during the long eighteenth century. ${ }^{69}$ Portuguese domestic medical practices evolved and benefitted greatly due to expatriate physicians and surgeons who chose to study in the more innovative, less intellectually restricted environment of Protestant Europe's universities, and then to communicate the fruit of their academic activities to colleagues at home. ${ }^{70}$

Azeredo's work is so compelling because he represents, and is a product of, a watershed moment in Portuguese medical history. His career offers a view into an era when medical understanding was in profound transition, on the cusp of methodological breakthroughs made possible by improved technologies and instrumentation for measuring minute processes of the human organism. Raised in colonial Brazil's relatively cosmopolitan capital, Rio de Janeiro, trained in medicine in Scotland and the Netherlands by some of the most

68 Pinto et al. 2005: 617-626.

69 Oliveira 2013: 153-188.

70 Araújo 1990: I, 49-72. For examples of converso physicians driven into exile by the Inquisition in the eighteenth century, see the following cases: Arquivo Nacional do Torre do Tombo (ANTT), Inquisição de Évora, processo nos. 5129, 6426, 9728, 3553 and 8686; Inquisição de Coimbra, processo nos. 6355, 6057, 7480, 163, 10098, 6312 and 7681; Inquisição de Lisboa, processo nos. 9980, 10429, 575, 8013, 9999, 6291, 2456, 3800, 629, 5278, 10073, 515, 6054, 9776, 6375, 3689, 138, 3686, 7178 and 1912. 
advanced medical theorists of the age, ${ }^{71}$ and posted to Angola as a colonial chief physician at the height of the transatlantic slave trade; these experiences gave Azeredo a unique perspective on Atlantic World colonial medicine - as well as a pivotal place in it, at least in the Portuguese sphere.

Azeredo's book on fevers and other diseases, Essays on some Maladies of Angola (1799), ${ }^{72}$ written during the period in which he was stationed in Luanda, Angola, significantly influenced methods for treating and containing contagious disease in metropolitan Portugal, especially practices for quarantining travellers arriving by sea outside of Lisbon. ${ }^{73}$ Treatment of patients' fevers owed no small part to methodologies that Azeredo pioneered and disseminated through his seminal publication. ${ }^{74}$

The significance of Azeredo's posting to Luanda, a pivotal node in the transatlantic slave trade during the closing decade of the eighteenth century, cannot be overstated. Luanda held a central position in the commercial networks of the Portuguese Atlantic. During Azeredo's tenure, this port served as the primary source for enslaved laborers for the plantations and mines of Brazil. Slave exports from Luanda averaged well over 20,000 persons annually during Azeredo's time there, which coincided with the very peak of the transatlantic slave trade, when Angola was the most active region in Africa, in terms of slave ship departures for the Americas. ${ }^{75}$

Thus, the young doctor had ample opportunity to learn about and treat disease conditions among captive peoples who had been force-marched from the Angolan interior to the Luanda port hinterland. Part of Azeredo's duties, after all, had a commercial as well as a medical dimension: he was to ensure the slaves' health so that this human merchandise could be loaded aboard crowded slave ships, without fear of fever spreading through such valuable cargos. ${ }^{76}$

In his practice, Azeredo, like his predecessors along the Angolan coast, mostly eschewed the numerous types of local medicinal plants employed by indigenous peoples in Africa (this stands in contrast to Portuguese medical experience in India, China, and Brazil, where colonists and missionaries readily embraced and assimilated native healing techniques). The majority of drugs

71 For example, the physician William Cullen (1710-1790), a professor of medicine at Edinburgh and leading figure in the Scottish Enlightenment, had a tremendous influence on Azeredo's training. See McGirr/Stoddart 1991: 23-26; and Stott 1986: 7-9.

72 Azeredo 1799.

73 Anonymous 2007: 5-7; 11-12.

74 Abreu 2013: 189-212.

75 See The Trans-Atlantic Slave Trade Database, Eltis et al. 2008.

76 An idea of what Azeredo experienced can be gleaned from Kananoja 2010: 443-465, Sweet 2011: 111-145 and Parés/Sansi 2011: chapters 1, 3, and 4. 
Azeredo described using in his practice came from South America (quinine), India (opium), and a considerable quantity of mercury from Iberia or Peru, thus exemplifying the interconnected nature of medicinal commerce within the contemporary Portuguese world.

Azeredo's Essays on some Maladies of Angola provides a number of examples that illustrate medicinal mercury use within the Portuguese empire at the close of the eighteenth century. The importance of his work lies in its being representative of the late Enlightenment transition to a modern empirical era in Lusophone medicine and science.

The five excerpted passages below provide telling details about Azeredo's practice, and, more importantly, illuminate his rationale for the application of mercury against fevers and related illnesses. Azeredo's treatise provides a rare glimpse into the mind of an early-modern physician who advocated strongly for the medicinal application of mercury. He was clearly aware of some of the negative effects that therapeutic use of mercury could cause, but he obviously thought that the benefits outweighed any long-term risks. Azeredo's commentary largely speaks for itself, so the passages below are provided with little additional analysis.

\subsection{Excerpt from the introduction: Azeredo advocates medical uses of mercury and opium}

In no African illness did I work with so little success for so long as with tetanus, and in no other did I succeed in discovering a treatment as certain. My treatment has been put into practice by other physicians who have attested to its efficacy and speed. My students have confirmed that no more patients have died of tetanus after they had been shown the method of treatment. The antidotes are not new remedies: they are mercury and opium; but I found it necessary for the cure [to be effective] for the medicine to be fresh, and the doses great. We are convinced that the ease with which we can now cure these outbreaks is a result of the large quantities of Peruvian bark [quinine] we administer to the patients, because the doses applied before did not have the results and advantages that we have since achieved. ${ }^{77}$

Thus, to treat tetanus in sub-Saharan Africa, Azeredo applied medicines that originated in India (opium), South America (quinine), and Iberia (mercury), all of which he was usually able to obtain in ample supply, even in a part of the empire that was, in terms of logistics, relatively marginalized, with difficult maritime supply lines. Clearly, this physician's record of addressing the symptoms of tetanus with the substances described has been sufficiently successful to

77 Azeredo 1799: 27-29. English translations by Stewart Lloyd-Jones, director of The Contemporary Portuguese History Research Centre. Boldface font added for emphasis. 
convince him of the absolute efficacy of his methods. Unfortunately, hospital and patient records that would have allowed for an independent verification of Azeredo's assertions are unavailable for further research. ${ }^{78}$

\title{
5.2 Two forms of mercury application: internal and external; indicated for blocked bowel
}

\begin{abstract}
Obstructions [of the bowel] must be assessed both during the rise of the fever and after. The idea that Peruvian bark is the cause of this in patients with fevers is completely wrong. In the past, physicians tended to confuse the effect with the cause. How many complaints are there in which much use is made of Peruvian bark and no obstructions ever appear? And how many times have there been fevers when no Peruvian bark has been administered? I am convinced that Peruvian bark is incapable of causing obstructions and I will continue to use it to treat fevers regardless of how large any obstructions may be. During paroxysms, each day I will embrocate the obstructed part of the gut with an eighth part of mercurial unguent, as this seems to me to be the best purgative that can be applied externally. However, once the fever has stopped rising, I will then use a range of internally applied treatments, the best of which I have discovered to be mercury, ammoniac gum and hemlock. Because I have had success with it, the administration of large doses of opium is the only treatment in which I have any faith in those cases in which either tetanus or lockjaw survive a fever. ${ }^{79}$
\end{abstract}

Note the highly toxic nature of the purgative agents that the physician Azeredo recommends (hemlock and mercury) to treat bowel obstruction. Moreover, Azeredo does not address the well-known effect of opium as a costive - an anti-purgative known to stop the movement of the bowels. That is, providing opium as a pain reliever was likely to interfere with Azeredo's desired effect in administering mercury as a laxative. That Azeredo had any opportunity to do much long-term monitoring of his patients following treatment is unlikely, since most, once "cured," were removed from his care, to be shipped as enslaved laborers to Brazil.

\subsection{Calomel used as a topical application to address hydrocephalus}

In cases of hydrocephalus, caustics can be applied to the neck, the forehead and the temples. Calomel can also be administered to stimulate the absorbent vessels; however, I have nothing to say about this because the fever will decide before the mercury is able to take effect.

78 Most archival documentation of the colonial hospital in Luanda where Azeredo worked (the Hospital da Misericórdia) is lost or has not survived. See Abreu 2013: 189-212.

79 Azeredo 1799: 191-193. 
To give patients strength, physicians will normally use remedies called antidotes and cordials; however, I have nothing to say about them because I never need to make use of them when I have good Peruvian bark and fine wine. ${ }^{80}$

\subsection{Mercury combined with rhubarb for dysentery}

Several laxatives have been recommended by different authors. Glauber's salt, cathartic salt, soluble tartar, herbal infusions, castor oil, or any other similar purgative can be used, according to the constitution of the patient. Cullen refused to use rhubarb because it is an astringent, dangerous in the case of dysentery. I have used it only occasionally and am unable to decide whether its astringency obstructs the treatment. Like in all things, I prefer to administer it, combining it with mercury according to Pringle's method. ${ }^{81}$ From this mixture emerges a smooth purgative that is just right for dysentery. Perhaps the mercury alters the rhubarb and increases its purgative qualities.

All irritant purgatives are harmful, even fatal, because they increase bowel pains and tenesmus [severe rectal cramping and pain]. I have seen some very deadly consequences from the use of jalap and scammony in a similar complaint. ${ }^{82}$

\subsection{Mercury unguent rubbing for tetanus - causes excessive saliva}

We must avoid bloodletting in those illnesses accompanied by weakness, or for which such debility is a proximate cause. Tetanus is such an illness in which the life force is both weak and fading.

As soon as the patient appears to have been struck by tetanus, I will have the back, neck and especially the thighs rubbed with a mercurial unguent. I will follow this by making the patient drink a high dose of opium tincture to ensure they have rest. If six hours pass during which the patient does not sleep, I will give them a double dose of opium, which will normally enable then to sleep for a few minutes. The next day I will have their body rubbed again with the mercurial unguent and in the morning will administer one hundred drops of opium tincture and the same again in the afternoon. I will repeat the application of the unguent on the third day, but with only half the dose of the previous day, and will continue to administer the same dosage of opium tincture.

Ptyalism [hyper-salivation] will appear during the course of the fourth day, which is when I will suspend the application of mercurial rubs. At this point I will continue to administer opium in the morning and afternoon until the trismus [lockjaw] has gone and the tongue is able to move. [...]

80 Azeredo 1799: 197.

81 "Rhubarb, half an eighth. Calomel, ten grains. Mucilage of Arabic gum, as much as is necessary. Form into pills.” Pringle 1775: 262, note 89.

82 Azeredo 1799: 261-263. 
As soon as the violence of both the trismus and the overall spasm diminishes, care should be taken to free the bowels, which will now respond to treatment. On this occasion a purgative will help nature remove the spasm while at the same time reducing the ptyalism that was a side effect of the mercury applied at the height of the illness. ${ }^{83}$

Some mistakenly believe that it takes days for the mercury to have an effect in the system. Their argument that the ptyalism only presents some time after the application of the mercury does not prove it takes time to have an effect, but rather it shows that the dose is limited, so that it does not produce saliva quickly. How often has a purgative containing mercury been administered, only for us to find the patient taking it on the next day with their tongue swollen, their face swollen, teeth shattered and spitting a lot? Everything depends on the dose and on the disposition of [each patient's] nature. ${ }^{84}$

\section{Conclusions}

The primary source documents presented in this article (each examined and explicated for the first time in an English-language publication) have furnished researchers who do not read Portuguese with rare information regarding the circumstances, techniques, and rationale for the application of medicinal mercury in the Portuguese medical context, in both the home country and in various colonial settings during the seventeenth and eighteenth centuries. Through the use and examination of translated, difficult-to-access Portuguese medical texts, this work has provided insight into how early modern Portuguese medical practitioners - some conventional licensed physicians and others missionary ecclesiastics who had received practical medical training - processed and employed mercury to treat a broad range of ailments.

Medical distribution of mercury in the Portuguese context relied on developed commercial networks, including familiar trade routes in the Atlantic World, and an established system of colonial ports throughout the eastern hemisphere. Thus, the movement of medicinal mercury between colonized areas and the Portuguese metropôle proceeded unimpeded, and employment of mercury as medicine became commonplace throughout the Portuguese imperial system.

Significantly, many of the remedies considered here were developed in geographically diverse regions, at several disparate locations throughout the Portuguese imperial world (including China, India, Angola, Brazil, and metropolitan Portugal). Perhaps unsurprisingly, these remedies often drew upon, and blended, common indigenous medical substances from the region where each healing compound originated.

83 Azeredo 1799: 319-321.

84 Azeredo 1799: 325. 
While medicinal uses of mercury in the Portuguese world were often strikingly consistent with comparative healing uses for mercury in other areas of Europe, it was in the colonies, where Portuguese practitioners had unique access to a range of indigenous medicinal substances, that innovative remedies compounds containing mercury and native healing plants - evolved in the context of a developing, culturally blended medical environment.

\section{Abbreviations}

ANTT Arquivo Nacional da Torre do Tombo (National Archives of Portugal).

ARSI Archivum Romanum Societatis lesu (Society of Jesus Archive; Rome, Italy).

BNF Bibliothèque Nationale de France (National Library; Paris, France).

BNRJ Biblioteca Nacional do Rio de Janeiro (National Library; Brazil).

HAG Historical Archive of Goa (Panaji, Goa, India).

MR Livros do Monções do Reino (annual volumes of official state correspondence to the Estado da Índia).

ff folhos (folios).

\section{References}

Abreu, Jean Luiz Neves (2013): "O saber médico e as experiências colónias no Ensaios sobre algumas enfermidades de Angola". In: José Pinto de Azeredo, Ensaios sobre algumas enfermidades de Angola. Edited by António Braz de Oliveira and Manuel Silvério Marques. Lisbon: Edições Colibri, 189-211,

Albernaz, Lorena Carneiro et al. (2010): "Investigation of plant extracts in traditional medicine of the Brazilian Cerrado against protozoans and yeasts”. Journal of Ethnopharmacology 131: 116-121.

Alden, Dauril (1996): The Making of an Enterprise: The Society of Jesus in Portugal, Its Empire, and Beyond, 1540-1750. Stanford, California, U.S.A.: Stanford University Press.

Amaro, Ana Maria (1992): Introdução da Medicina Ocidental em Macau e as Receitas de Segredo da Botica do Colégio de São Paulo. Macau: Instituto Cultural de Macau.

Anonymous (1766): Colecção de Varias Receitas e Segredos Particulares das Principais Boticas da Nossa Companhia de Portugal, da India, de Macao e do Brazil. Rome, Italy: Archivum Romanum Societatis lesu [ARSI], nr. Opp. NN. 17.

Anonymous (2007): Porto Brandão, A Terra e o Tejo 2007: Almada: Centro de Arqueologia de Almada. 
Azeredo, José Pinto de (1799): Ensaios sobre algumas enfermidades de Angola. Lisbon: Regia Officina Typografica.

Araújo, Maria Benedita (1990): “Médicos e seus Familiares na Inquisição de Évora”. In: Inquisição: Comunicações apresentadas ao $1^{\circ}$ Congresso Luso-Brasileiro Sobre Inquisição. Edited by Maria Helena Carvalho dos Santos. 3 vols. Lisbon: Sociedade Portuguesa de Estudos de Século XVIII e Universitária Editora, I, 49-73.

Boyajian, James C. (1993): Portuguese Trade in Asia Under the Habsburgs, 1580-1640. Baltimore: Johns Hopkins University Press.

Brown, Kendall W. (1994): “The Spanish Imperial Mercury Trade and the American Mining Expansion under the Bourbon Monarchy". In: The Political Economy of Spanish American in the Age of Revolution, 1750-1850. Edited by Kenneth J. Andrien and Lyman L. Johnson. Albuquerque: University of New Mexico Press, 137-167.

Cardoso, Adelino (2013): “Pinto de Azeredo: um médico livre, positivo e eclético". In: José Pinto de Azeredo, Ensaios sobre algumas enfermidades de Angola. Edited by António Braz de Oliveira and Manuel Silvério Marques. Lisbon: Edições Colibri, 267-276.

Disney, Anthony R. (2009): A History of Portugal and the Portuguese Empire. 2 vols. Cambridge, U.K.: Cambridge University Press.

Eltis, David et al. (eds.) (2008-ongoing): The Trans-Atlantic Slave Trade Database. Open Source Database: www.slavevoyages.org.

Goldwater, Leonard J. (1972): Mercury; A History of Quicksilver. Baltimore: York Press.

Hernández Sobrino, Ángel M. (1999): La Real Mina de Azogue de Huancavelica (Perú) Madrid: Minas de Almadén y Arrayanes.

Hernández Sobrino, Ángel M. (2003): Oficios Mineros de Almadén; Siglos XIII-XIX. Madrid: Minas de Almadén y Arrayanes.

Kananoja, Kalle (2010): "Healers, Idolaters, and Good Christians: A Case Study of Creolization and Popular Religion in Mid-Eighteenth Century Angola". The International Journal of African Historical Studies 43.3: 443-465.

Lane, Kris (2010): Colour of Paradise: The Emerald in the Age of Gunpowder Empires. New Haven: Yale University Press.

Leicester, Henry M. (1956): The Historical Background of Chemistry. New York: John Wiley and Sons.

Leitão, Henrique (2007): A Ciência na «Aula da Esfera» no Colégio de Santo Antão 1590-1759. Lisbon: Comissariado Geral das comemorações do V centenário do nascimento de São Francisco Xavier.

Leite, Serafim, S.J. (1953): Artes e Ofícios dos Jesuítas no Brasil (1549-1760). Lisbon: Edições Brotéria.

Leite, Bruno Martins Boto (2013): “Verdes que em vosso tempo se mostrou. Das boticas jesuíticas da Província do Brasil; Séculos XVII-XVIII”. In: Usos e circulaçao de plantas no Brasil; Séculos XVI-XIX. Edited by Lorelai Kury. Rio de Janeiro: Andrea Jakobsson Estúdio Editorial, 52-93.

Longworth Dames, Mansel (trans.) (2002 [1918-1921]): The Book of Duarte Barbosa. 2 vols. New Delhi: Asia Educational Services.

Maia, Patrícia Albano (2012): Práticas Terapêuticas Jesuíticas no Império Colonial Português: Medicamentos e Boticas no Século XVIII. Unpublished doctoral dissertation, Department of History, University of São Paulo.

Matilla Tascón, António (1958): Historia de las Minas de Almadén; Vol. I: desde la época romana hasta el año 1645. Madrid: Minas de Almadén y Arrayanes. 
O‘Neill, Charles E./Dominguez, Joaquín M. (eds.) (2001): Diccionario Histórico de la Compañia de Jésus Biográfico-Temático. 3 vols. Rome: Institutum Historicum.

McGirr, E.M./Stoddart, W. (1991): "Changing theories in 18th-century medicine: The inheritance and legacy of William Cullen". Scottish Medical Journal 36.1: 23-26.

Parés, Luis Nicolau/Sansi, Roger (eds.) (2011): Sorcery in the Black Atlantic. Chicago, Illinois: Chicago University Press.

Pringle, John (1775): Observations on the diseases of the army ( $7^{\text {th }}$ ed.). London: Printed for W. Strahan, J. and F. Rivington.

Oliveira, António Braz de (2013): “Do Rio a Lisboa, passando a Luanda: achegas para uma biografia de José Pinto de Azeredo". In: Ensaios sobre algumas enfermidades de Angola. Edited by António Braz de Oliveira and Manuel Silvério Marques. Lisbon: Edições Colibri, 153-187.

Parry, J. H. (1966): The Spanish Seaborne Empire. Berkeley, Los Angeles: University of California Press.

Pike, Ruth (1983): Penal Servitude in Early Modern Spain. Madison, Wisconsin: University of Wisconsin Press.

Pinto, Manuel Serrano, et al. (2005): “O medico brasileiro José Pinto de Azeredo (1766?-1810) e o exame químico da atmosfera do Rio de Janeiro". Manguinhos: História Ciências Saúde 12.3: 617-673.

Regimento dos Familiares do Santo Ofício (1694): Lisboa: Officina de Miguel Manescal. British Library Manuscripts Room, Add. 20: 953, ff. 173-174.

Santo António, Dom Caetano de (1711): Pharmacopea Lusitana reformada methodo pratico de preparar os medicamentos na fórma Galenica, \& chimica (...). Lisbon: Impressão no Real Mosteyro de São Vicente de Fóra.

Santos Filho, Licurgo de Castro (1947): História de Medicina no Brazil, do Século XVI ao Século $X I X$. 2. vols. São Paulo: Editora Brasiliense Ltda.

Sousa Dias, José Pedro/Pita, Rui (1994): “A Botica de S. Vicente e a Farmácia nos Mosteiros e Conventos da Lisboa Setecentista”. In: A Botica de São Vicente de Fora. Lisbon: Associação Nacional das Farmácias.

Sousa Dias, José Pedro (1991): Inovação Técnica e Sociedade na Farmácia da Lisboa Setecentista. Doctoral dissertation of the Universidade de Lisboa, Faculdade de Farmácia.

Stein, Stanley J./Stein, Barbara H. (2000): Silver, Trade, and War: Spain and America in the Making of Early Modern Europe. Baltimore: Johns Hopkins University Press.

Stott, R. (1986): “William Cullen and Edinburgh Medicine: a Reappraisal”. The Society for the Social History of Medicine Bulletin 38: 7-9.

Sweet, James H. (2011): Domingos Alvares, African Healing, and the Intellectual History of the Atlantic World. Chapel Hill, North Carolina: The University of North Carolina Press.

Walker, Timothy (2013): "The Medicines Trade in the Portuguese Atlantic World: Dissemination of Plant Remedies and Healing Knowledge from Brazil, c. 1580-1830". Social History of Medicine 26.3: 403-431.

Walker, Timothy (2011): "Stocking Colonial Pharmacies: Commerce in South Asian Indigenous Medicines from their Native Sources in the Portuguese Estado da Índia". In: Networks in the First Global Age (1400-1800). Edited by Rila Mukherjee. New Delhi: Primus Press, 141-170.

Walker, Timothy (2009): "Acquisition and Circulation of Medical Knowledge within the Portuguese Colonial Empire during the Early Modern Period”. In: Science, Power and the Order of Nature in the Spanish and Portuguese Empires. Edited by Daniela Bleichmar et al. Redwood City, California: Stanford University Press, 247-270. 